\title{
The Research on the Function of College Students' Ideological and Politi- cal Education to College Students' Employment
}

\author{
Wen-Fei Zhou ${ }^{1, *}$ and Lequn $\mathrm{Li}^{2}$ \\ ${ }^{1}$ Hunan Vocational College of Science and Technology, Changsha, 410118, Hunan, China; ${ }^{2}$ Hunan Mass Media \\ Vocational Technical College, Changsha 410100, Hunan, China
}

\begin{abstract}
The problem of College Students' employment is a concern of the Chinese government. Art College Students Ideological and political education and career education with art college students employment situation of development, it can't solve the art college students employment difficult problem is the outstanding problem faced in the ideological and political education in Colleges and universities. In order to accurately understand the College Art College Students' Ideological and political education present situation, this paper by means of questionnaire, interview and informal discussion, of four University of arts college students were investigation of the ideological and political education present situation and the concept of employment, basically proved by the actual situation of Art College Students' ideological and political education and employment education. The on how to further strengthen the art college students employment guidance education and ideological and political education, the organic combination of the two in order to improve the effect of Ideological and political education has conducted the thorough research, and puts forward the concrete measures.
\end{abstract}

Keywords: Art college students, employment, ideological and political education, the whole process of education.

\section{INTRODUCTION}

The ideological and political education of college students is a very important part of our party's ideological and political work. The ideological and political education in Colleges and universities is the basis of all teaching work [1]. The basic goal of the ideological and political education of colleges and universities is to Marxism Leninism, Deng Xiaoping theory, "Three Represents" and the scientific development view, the guidance of the important thought of, the cultivation of certain ideological and political qualities and scientific and cultural qualities of the qualified students [2].

At present, is a process in the development of the popularization of China's higher education, professional art continues to heat up, many had no professional art colleges and universities have begun to offer art majors, and enrollment [3] continues to expand the scale, but the current market for the growth rate of art talents demand growth significantly less than the art professional capacity of students, which leads to demand is far greater than the supply. In increasingly difficult employment, employment concept of art graduates is relatively backward, the emptiness of the spirit of the pursuit, poor employment ability, lack of awareness of integrity, vulnerable employment psychology and so on has seriously affected the art graduates successful employment [4].

According to the latest statistics from the Ministry of education of China, in 2014, our graduate students up over

\footnotetext{
*Address correspondence to this authors at the Hunan Vocational College of Science and Technology, Changsha, 410118, Hunan, China;

E-mail: cyztoe456@163.com
}

$7 \mathrm{~m}$ people, than last year students graduated from an increase in the number of 28 million, the art college graduates will exceed 700000 people [5]. This is the most serious problem currently facing our country government and the colleges and Universities. At present, the issue of College Students' employment has been highly valued by all levels of our country, and it is a very important job for the students to carry out the employment education [6].

Employment education is a work involving pedagogy, psychology, economics, management and other disciplines. This requires that the staff should have the relevant knowledge structure in the ideological and political education of the art students. But now engaged in the work of the teaching staff, full-time political workers most are not ideological and political education professional graduate [7], and engaged in full-time employment guidance work basically are from student work department and other departments to deploy, knowledge structure but also to adapt to not art education of College Students' employment.

Engaged in art class of employment of College Students Ideological and political education of staff, especially counselors generally very young [8], lack of life experience and social experience, lack of Ideological and political education theory knowledge and professional training, there is a lack of the practical experience of the ideological and political education of art major students of employment guidance force from the heart, can't meet the students' needs [9].

On the one hand, the graduates of the employment of college students education cannot meet the requirements, on the other hand traditional colleges and universities students ideological and political work of political color relatively thick, give students the impression is "superior", and the daily life 
of students is out of touch, and college students' rich and colorful social will activities out of tune. Contemporary art college students pay more attention to the pursuit of personal success or success. Consider the problem more realistic, they pay attention to is can according to the market value of the outcome measure, and their outlook on life [10], world outlook, values are formed, for social life, have many doubts unresolved. Employment problem, interpersonal communication problems, learning pressure, economic pressure is troubled by the problem of university students' most at present, especially the problem of employment. However, whether it is the creation of the University can solve a series of problems faced by the current art students, Chinese high school art students employment guidance and ideological and political education work has clearly out of touch.

Art college students as an important part of college students, both the common characteristics of Arts and science college students, but also has its own uniqueness, the ideological and political education way is not only different in liberal arts majors and difference in pure art class colleges and universities, how to combine the art college students' Ideological and political education and career education is a new task that is worth studying.

\section{ANALYSIS OF THE IDEOLOGICAL AND POLITI- CAL EDUCATION OF ART STUDENTS IN THE PER- SPECTIVE OF EMPLOYMENT}

\subsection{The Design and Distribution of the Questionnaire}

Questionnaire survey method (questionnaire, survey by unified design of the questionnaire to selected respondents to understand some cases or Consulting survey opinion a survey method, it is a kind of digging in actual situation of research and its biggest goal is gathering, accumulating a certain target groups of the scientific study of the properties of the basic data.

For detailed insights into the art college students employment ideological status quo, this paper carefully to determine the object of investigation, investigation object is mainly the art of Xi'an University of technology, Xi'an University of technology, Xi'an Academy of fine arts and Northwestern University Students and to other students to conduct random checks. The implementation of the questionnaire is divided into four stages: the first stage, interview with the famous ideological and political education experts in the range of our city. The second stage, analyze the existing research results and combine with the actual situation of College Students' Ideological and political education in the art of Xi'an Technological University, determine the contents of the investigation, including: personal circumstances, political ideas [11].

The employment situation, the concept of career, career, graduation, graduation whether the change of their own conditions, etc. There are 32 questions in the questionnaire, and it is very comprehensive and has a certain representative, the basic coverage of the study. The third stage, on the small scale of the initial questionnaire based on 30 people, combined with survey feedback to adjust the actual situation of questions in the questionnaire, and invited experts to evaluate the Objective Adjustment Questionnaire, fully ready for the subsequent formal questionnaire. The fourth stage, the implementation of a formal questionnaire and carefully test the activity of the reliability and validity of the questionnaire is qualified.

In order to evaluate the validity objectively, through issuing questionnaire index validity test expert evaluation table, experts have evaluated the contents, design, structure and measure of the questionnaire. This investigation shared 1200 questionnaires, 1183 copies, the effective recovery rate of $98.5 \%$. Questionnaires, survey of valid questionnaires were detailed code carefully organize and establish the questionnaire data [11], questionnaire data using SPSS13.0 software for statistical processing, and again the reliability of the questionnaire was tested, the reliability of the questionnaire reached 0.85 , combined with the questionnaire validity inspection expert evaluation form "can show that this questionnaire has certain validity and reliability, conform to the requirements of sociological investigation and relevant statistical analysis can be carried out.

The self-designed questionnaire survey, the questionnaire is mainly designed by the author completed, part of the subject design reference topics related to the research results, some reference in the references have been described in detail [12].

\subsection{Questionnaire Analysis}

After the recovery of the questionnaire, this paper on valid questionnaires were detailed analysis, analysis results are summarized into six aspects, which are analysis, analysis of employment, salary expectation analysis, expected work area analysis, the analysis of the teaching effect of Ideological and political course, current situation of employment guidance of concept of value of life. The details are as follows:

1) Analysis of the values of art students in the perspective of employment

The value is the subject's evaluation criteria and the fundamental viewpoint of the value and the value of the subject. In this paper, the goal of life, for life attitude, judgment standard of value of life, what kind of life is success in life of these four questions of questionnaire survey, to understand the art students' values. Returned questionnaires from the point of view, as shown in Fig. (1) in the treatment of life goals is what this question $46 \%$ of students to make money for the purpose of[13], $22 \%$ of the students choose to achieve their life values, and $26 \%$ of students choose to live comfortably. From the questionnaire, it can be seen that the value orientation of college students in the school art has been changed obviously with their parents. In the past people's ideal is for communism struggle for life, collectivism is the core part of individual value orientation; now, when asked about the life pursuit, $33 \%$ of the students chose aim of life is personal fame, profit, up to $42 \%$ of the students choose never thought this problem.

With the development of science and technology, the continuous emergence of new technology and high-tech, art students living in the social environment has occurred earth shaking changes, the value of the western capitalist countries view through the Internet and other media in imperceptible 


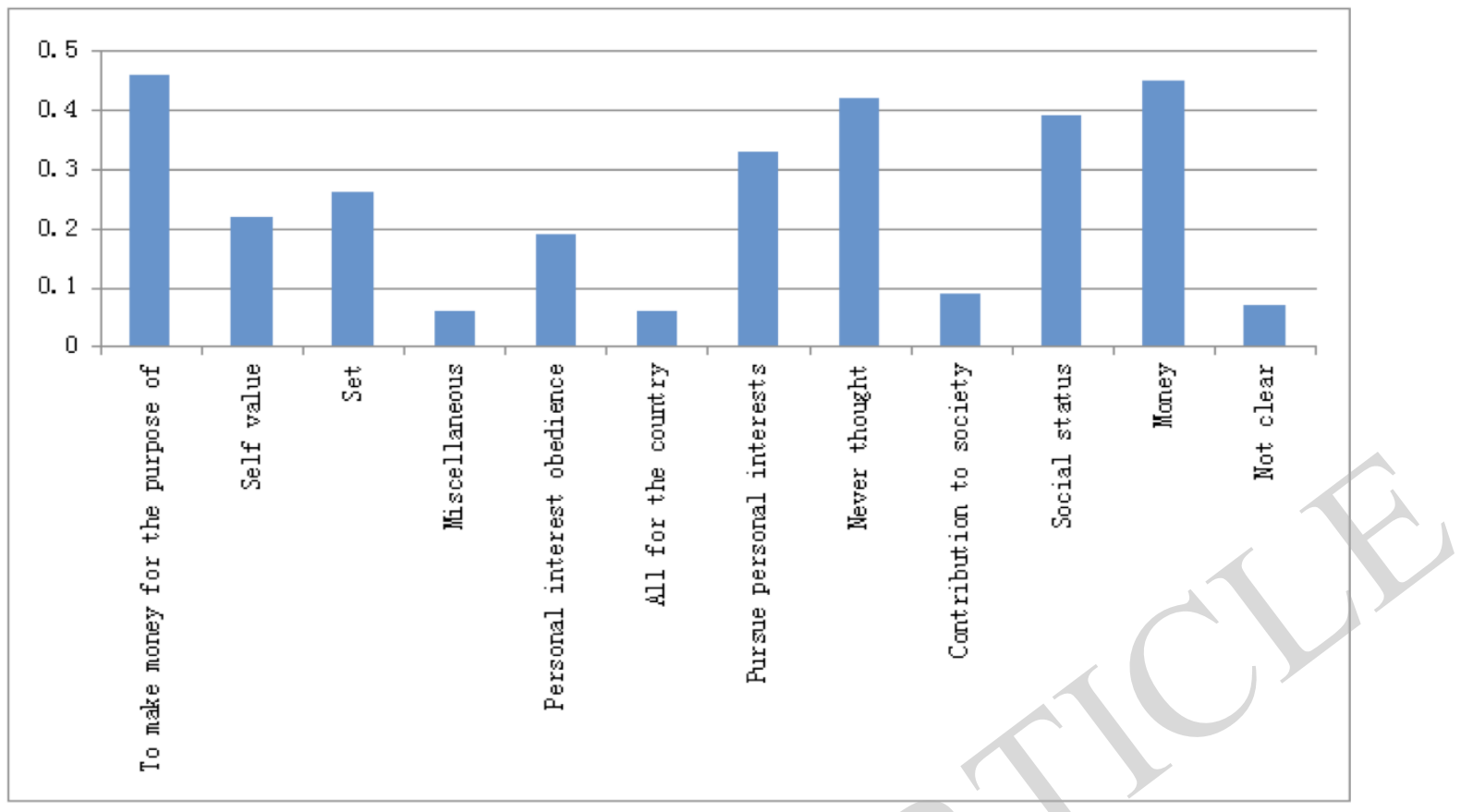

Fig. (1). The analysis chart of the value of art students.

in to our young generation, penetration, influence on the ideology of college students is deepening day by day. The art students face a variety of social phenomena of complex changes, the first consideration is the self-value, showing obvious realism tendency. But from the whole, the world outlook, outlook on life and values of art students are positive and positive [14].

2) analysis of the employment view of art students in the perspective of employment

Since 1999, China's college enrollment, higher education entered the stage of rapid development, education, especially for the students of art increasingly severe unemployment problem, art university graduate employment problem is not only related to the future and destiny of every student, but also directly affect the healthy development of the higher education in our country is a great deal that related to social stability, the cause of reform and opening up whether can continue to move forward.

Everyone wants to find a job that he likes, but in the face of severe employment pressure on how to get employment, art students appear very confused. In answer to "do you think that your professional predominates in the job?", such as Fig. (2) other students think their own professional dominated in the job of $37.9 \%$, that do not have the advantage of only $42 \%$, not clearly accounted for $11 \%$ and other accounted for about $9 \%$, and most art students of their own professional obviously not confident or don't understand that their own professional in the job for advantage answer only accounted for $26 \%$, that does not occupy the advantage of up to $50 \%$, unclear accounted for $19 \%$, other answer accounted for $5 \%$. But in view of the nature of their own professional work counterpart problem, such as art classes in Fig. (3) up to $42 \%$ of the students think that work doesn't have to be with professional counterparts, $38 \%$ of the students that can be associated with the professional work, up to $20 \%$ of the students think professional work of matter has nothing to do, but other professional students only 35\% think work doesn't have to be professional and counterparts, $48 \%$ of the students that can be associated with the professional work, $17 \%$ of the students think that professional and working properties are not necessarily linked. Such as Fig. (4) when asked if he would be willing to give up the professional, to choose an unrelated work to work, up $56 \%$ of the Art College of people willing to employment and careers, only $22 \%$ of the students are not willing to, July $14 \%$ of the art students choose their own businesses, and $8 \%$ said are likely to continue their studies. Other professional students only $47 \%$ of people willing to employment, up to $12 \%$ of the students hope to step in place to employment, and have fixed income, only $7 \%$ of students choose their own businesses, and 34\% said willing to continue their studies. In temporarily unable to achieve their ideal situation, first find a temporary job to job experience, and then choose love their lifelong career has become the mainstream of employment concepts of the Chinese students. The data show that the proportion of college students choosing first choice of employment is very high, and the employment adaptability of art students is significantly higher than other students.

\subsection{The Analysis of the Differences Between the Artistic Students and Other Majors}

Through a detailed analysis of the questionnaire, we can find that the art students are also superior to other students in the employment aspect and have a disadvantage in the employment.

1) The employment advantage of the art students

The employment advantages of the art students mainly have the following two points:

A, career choice flexibility 


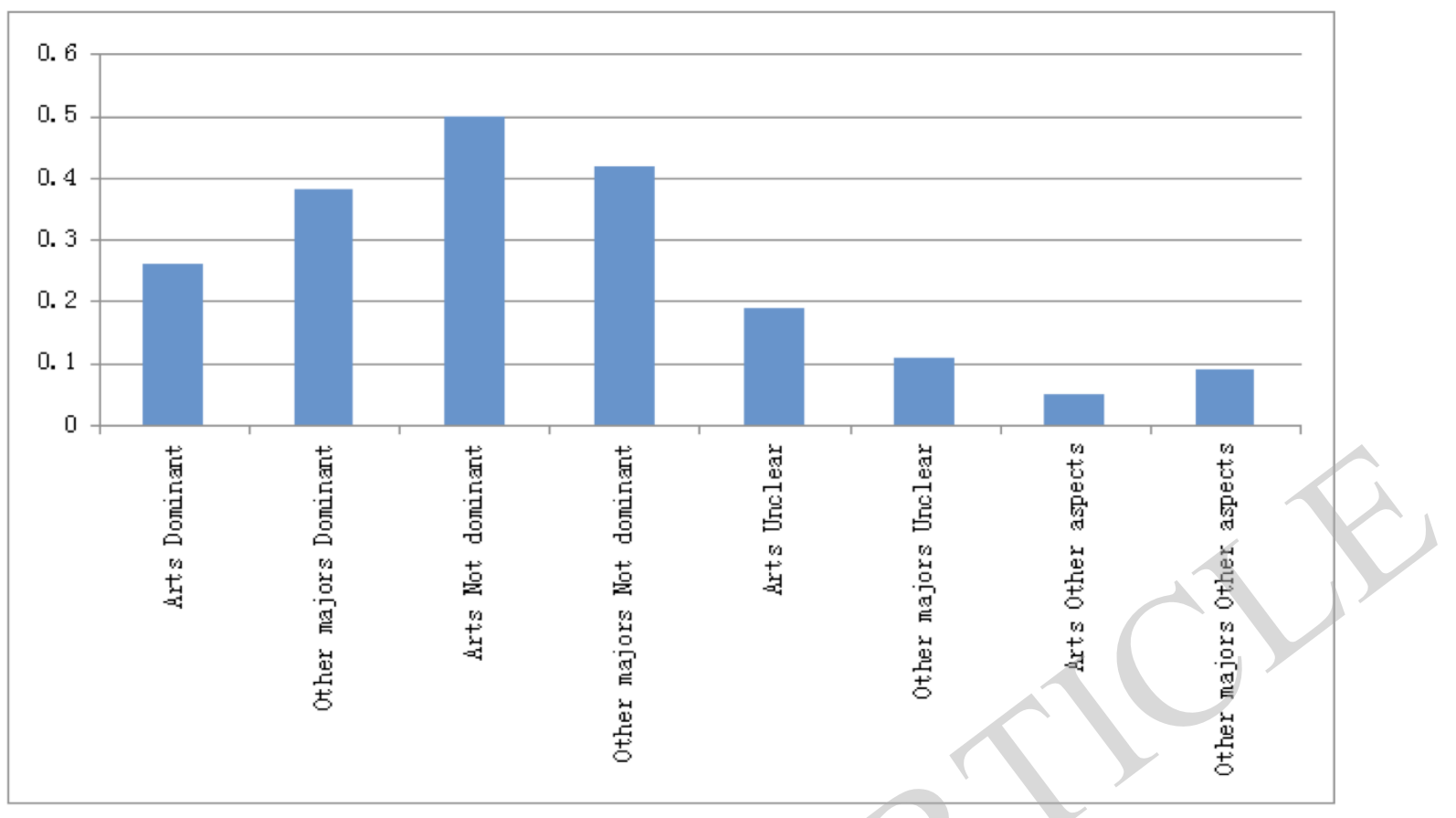

Fig. (2). Contrast of professional advantage.

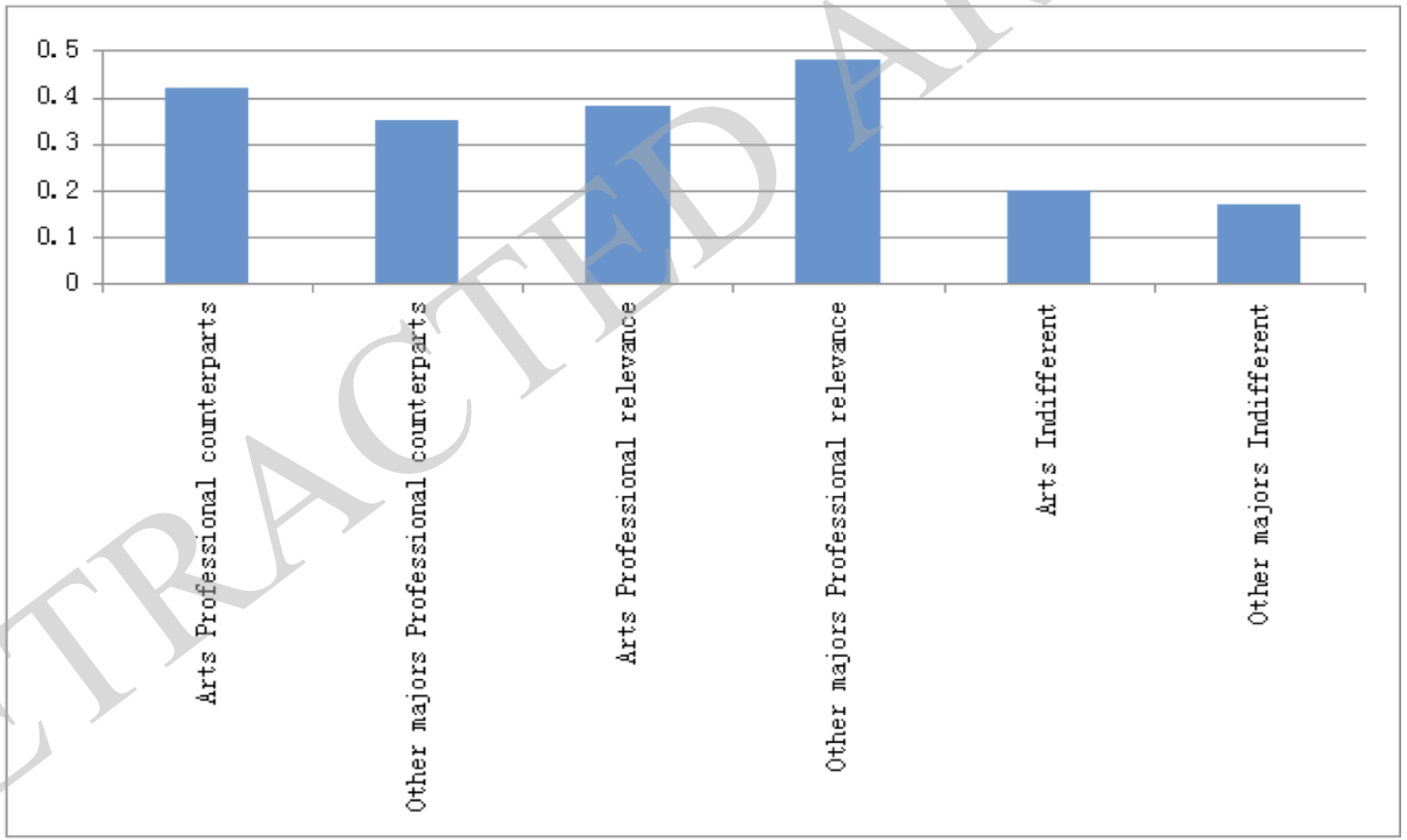

Fig. (3). Professional counterparts contrast.

Compared with other students, art students more distinct personality, many graduates unwilling to employers to sign the employment agreement, become self-employed persons, even some students during the period of school began his company solicit business design.

From the questionnaire can be seen, the art students most is not willing to employing unit signed employment agreements, the proportion is as high as to sign an agreement of the proportion of $34 \%$, the purpose is to facilitate the job hopping, and $18.2 \%$ of students choose to look at the situation say; and other professional college students that don't need signed the employment agreement only $7 \%$. For some art students, as long as the employer have a job doing it, some graduates don't even talk to employers to sign the labor contract, this time after this unit orders, finished to pick up orders for other units, according to the workload settlement payment, since has more freedom. Generally, the choice of the design unit of college students are mostly private enterprise, the boss is willing to decide how much according to business number of employees. This kind of employment way has many disadvantages, but from another aspect may reflect the artistic kind university student employment flexibility is quite big [15]. 


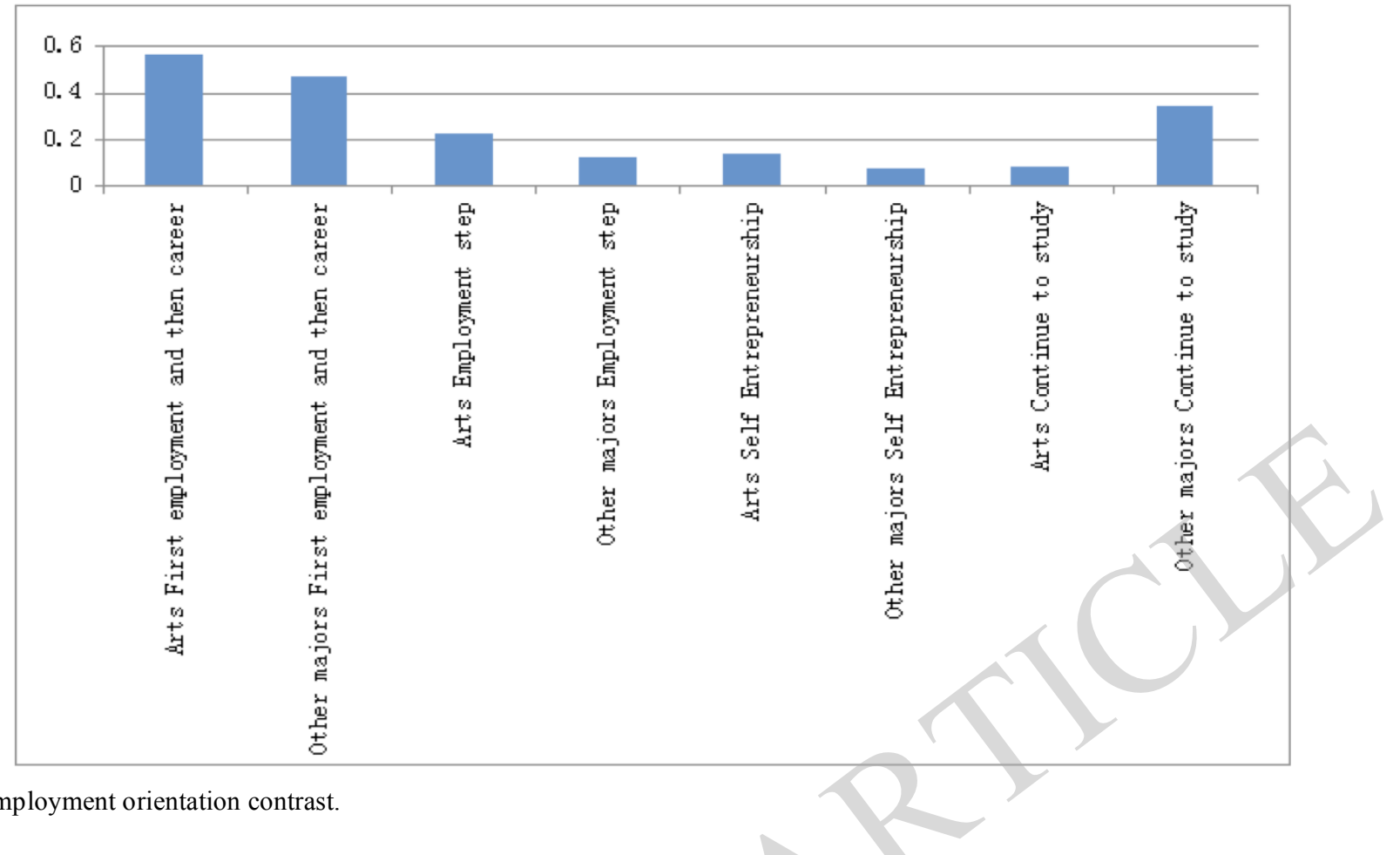

Fig. (4). Employment orientation contrast.

\section{B, good at self Entrepreneurship}

The art students have distinct personalities, independent personalities, they are accustomed to thinking independently and have strong self-awareness. Art University industry is rich in emotional, eager to the depth of ideological exchange, and willing to express their ideas, more strong sense of self entrepreneurship. In addition, art college students to start their own businesses abuse is relatively low, incorporated a design company or the design of rooms need only a few million yuan of funds, commitment to planning, advertising, graphic design, and so on a series of work. This also further promote the art of college students to self start.

2) The employment disadvantage of the art students

From the perspective of psychology and morality, the employment disadvantages of art students are mainly the following two aspects:

A, employment expectations too high, employment intention is not strong, weak awareness of career planning

The analysis of the questionnaire shows that the employment expectation is one of the main reasons for the difficulty of the artistic students' employment. Many college students the preferred employment unit is the institution, unwilling to grassroots work. Affected by the impact of the world financial crisis, many employers reduces the wage, job fair in some post salary is only one thousand yuan, the price and migrant workers salary almost, so many students are not willing to vote resume, "do not become high, low not", part of the arts students would rather be "eating the old family" would not like to go to the employment. Part of the graduates themselves do not take the initiative to find work, do not want to participate in job fairs, and even personal recruitment materials is not ready to, do not want to participate in organized by the school employment guidance activities, even supply and demand will be met are not willing to par- ticipate in, and the art students completely rely on parents according to social relations, the employment to their parents.

Art students generally in the graduation stage of the employment awareness, the lack of clear career planning awareness. A lot of low grade art students, during the school don't realize about employment problem, until graduating when it is in a hurry to find a job, for their lack of a reasonable position, so in the course of employment easily lost.

$\mathrm{B}$, professional morality and legal awareness is not strong, the lack of ideals and beliefs, career choice

Part of the art college in the recruitment process, fraud, tampering grades, forged certificate of award-winning, free to fill out the resume, as long as employment anything dared to knitting, lack of awareness of good faith. And part of the graduates in the course of contract signing promise, does not fulfill the contract, as long as it's profitable arbitrary breach of contract, this behavior to a certain extent lead to art college students employment market order into chaos, but also the damage to the reputation of the school. Further, and even affect the his classmates and the next student employment.

Some art university graduates choose only first tier, second tier cities and developed areas of the southeast coast of employment, refused to work in rural areas and the West. Although the current national policy to the rural and western regions of the tilt, but from the current situation, the short term can not change the employment trend of college students. Can be seen, in the face of reality and art university graduates to focus on is the interests of the person in front of, ignored personal ideal and national interests, career utilitarian, lack of dedication to the society.

The problems listed above are the shortcomings of the current college students, but these shortcomings are more prominent in the body of art students. 
Currently China's higher education has entered the popularization period, do art professional, more and more universities, with respect to the prophase of enrollment expansion in Colleges and universities, the mental state of art students have the obvious change. The analysis of the questionnaire can find that the ideological problems of the art students are mainly the following three:

1) "High investment and high returns" employment mentality

Compared with other professional college students, the contradiction between College Students' income expectations and social reality is very prominent.

As is well known, art major is a high cost, learning cost is much higher than its professional. An undergraduate student of the arts has spent more than four yuan for one hundred thousand years. So parents and students are expected to get the corresponding high return. Under the influence of this idea, art students tend to find high income and professional work when applying for a job. But the art design industry practitioners have a strong hands-on skills, more emphasis on the employment of experienced staff. This year's graduates lack of practical experience so the salary will not be high. Some private enterprises in order to reduce the cost, choose to recruit high school graduates migrant workers and then carry out the short-term training software, to solve the problem of manpower shortage. This is also a reason for the employment of art students difficult.

2) Do not have freedom of occupation rather choose to switch to the employment mentality

The cultural level of the art students is generally not high, and it is a universal psychology for the students in the art of employment. Many art students from primary school began to learn art, almost gave up on other cultural studies, especially the basis of mathematical physics is very poor. It is due to art students' cultural basic course is not good, to learn new technology to switch to the difficulty is very big, so most of the art students in employment hope to find a professional counterparts or relevant professional work, if you can not find, many graduates prefer freelance is reluctant to switch to engage in other work.

3) Money worship, hedonism of the outlook on life and values

Because of professional reasons, the art students than other students more opportunities to contact western culture, so by the influence of the thinking of western capitalism is relatively large, many art students' Outlook on life, world outlook, outlook on talents and the choosing profession view is not correct. Blindly follow the trend, the blind pursuit of material comforts, lack of spiritual beliefs, money worship and other bad ideas spread in the art students. And part of graduates is the apparent lack of hard-working psychological preparation, to develop during the period of school and the loose of the life style brought to the job. This is a common problem for contemporary college students, but it is more evident in the body of art students. So, in the same conditions, most employers would rather hire other students than hire art students.
3. PROBLEMS AND REASONS OF IDEOLOGICAL AND POLITICAL EDUCATION FOR ART STUDENTS FROM THE PERSPECTIVE OF EMPLOYMENT

\subsection{Problems in Ideological and Political Education for Art Students}

In recent years, the ideological and political education curriculum has been greatly developed, the ideological and political education course began to pay attention to the college students, especially the employment of art students, and achieved initial results. Many colleges and universities including the University of art began to establish employment guidance institutions, the creation of the relevant lectures and courses for the arts students for career guidance. But because the tight combination of employment guidance activities and ideological and political education curriculum can't, employment guidance activities in the thought political education method and content can not fully meet the requirements of the current form, the function of Ideological and political education in the employment guidance didn't get fully play, the ideological and political education of high school art class specialized still exist many problems.

\subsection{The Reasons for the Problems in the Ideological and Political Education}

From the employment point of view, the ideological and political education for art students has many reasons, there are objective reasons, there are subjective reasons, the main reasons are the following two aspects.

Ideological and political education environment is to point to in the process of Ideological and political education, education object directly contact to, influence ideological and political education of all the external conditions for the sum of, including three aspects of spiritual environment, social environment and the natural environment. The social environment is the core of the environment of ideological and political education.

At present, China's social development is in the social transformation, the whole society is undergoing profound changes in all aspects. The environment of Ideological and political education is changing, which makes the ideological and political work harder and harder in the new period. Ideological and political education work in the changing environment is mainly manifested in the following aspects: China's economy is in a period of rapid development, changes in the pattern of world politics, changes brought about by the expansion of enrollment in Colleges and universities, the employment of college students changes.

The ideological and political education in Colleges and universities is the basic condition for the ideological and political education for the students of the arts. The quality of Ideological and political education in colleges is one of the decisive factors that affect the effect of Ideological and political education. The lack of the ideological and political education work team leads to the effect of the ideological and political work of the university art students, which has a negative effect on the students' employment. The ideological and political education work team lacks the construction concrete performance for the following three points: the 
troop number is insufficient, the knowledge structure is unreasonable, the age structure is unreasonable.

\section{REFORM THE IDEOLOGICAL AND POLITICAL EDUCATION FOR ART STUDENTS}

\subsection{Strengthen Student Employment Management}

Strengthen employment during the art students' Ideological and political education, strengthening employment during the college students management work, and guide the students to correctly understand and deal with all kinds of problems in employment, in a timely manner to resolve their doubts and culture art college students to establish a strong legal awareness knowledge and correct moral concept, help students to consciously abide by college students' employment market rules, and consciously resist the illegal and unhealthy phenomenon.

\subsection{Implement Full Employment Education}

Full employment education philosophy is refers to the education curriculum of employment guidance for college students through to the concept of the whole process of the whole university stage, and scientifically put forward the reasonable and practical, concrete operation solutions to the problems. Purpose is through a complete implementation, the art students as possible early to establish correct concept of employment and learning and employment combined concept, thus the employment pressure into motivation to learn, ultimately improve the employability of college art students ensure the job quality, the art college students career counseling education has a good practical effect. Specific implementation plan is as follows:

A freshman in college, college students, just began to leave their parents, began to enter the University of collective life. The impulses of youth so that they have a strong desire to move forward determined taught, however, from the home of the harbor and that they easily confused, lax, anxious mood. This education departments in Colleges and universities should combined with school education and military training, helping art college students to establish scientific value concept and talent concept, step by step guide art college students to continue to understand the social from all walks of life, preliminary personal career planning.

In the university grade two, art students should continue to learn professional knowledge, broaden their knowledge range.

Third year university, art students' values are preliminarily formed, has begun to enter early career, at this time, education departments in Colleges and universities should through the organization visited alumni achievers and talent market, through to the front-line personally research activities, let art students personally feel strong demand for talents from the whole society, through to this series is for the activities of the organization as the carrier, and actively carry out the quality of art students to expand education, and actively guide the art college students continue to strengthen training all the skills needed in their employment competition, especially the interpersonal communication ability, innovative thinking ability, hands-on practical ability etc.
To the fourth grade university, higher education departments should focus on art students' employment situation, employment policy, employment process, job skills and job psychological targeted guidance, at the same time, the student work department shall strengthen the art students to correct the values of reeducation and employment psychology education, the art students for their smooth entry into the social ideological and moral and psychological preparation, forming a good job attitude, and actively guide the art students continue to speed up the individual socialization process, thus consciously realize the transformation from art students to the role of social art worker, grasping the opportunity of employment adjustment, application of employment policy correctly, seize the favorable employment opportunities, the smooth realization of their own occupation ideal and life value.

\subsection{Enrich the Content of Ideological and Political Edu- cation for the Art Students}

The society is the test room which tests the university student overall quality, the university stage study mainly is in order to participate in the work reserve each kind of knowledge and grasps each kind of skill, thus the Bureau individual employment ability. Employment ability, is refers to the practitioners engaged in the professional needs of the various abilities of the sum, in addition to outside the reasonable knowledge structure, excellent professional skills, professional knowledge and skills also includes a excellent ideological quality, necessary career skills and interpersonal skills, strain capacity.

\subsection{Innovative Ideological and Political Education Meth- ods and Means}

Comrade Jiang Zemin pointed out that the key to college students' Ideological and political work is must be attractive and effectiveness to in-depth understanding of young students ideological and psychological state, and at the same time, we should pay attention to the appropriate ways and means. With China's position in the international and domestic situation is constantly changing, the art students state of mind also gradually undergoing complex and profound changes, a lot of problems that, educators must be innovative methods of Ideological and political education to adapt to the changes of.

\section{CONCLUSION}

The problem of College Students' employment is a difficult problem for the Chinese government at present. Chinese government leaders repeatedly stressed that the issue of employment is the fundamental issue to achieve the livelihood of the people. To achieve smooth employment is the key to protect the interests of the people of the people. College students are the country is extremely precious talent resources, is our country implementation force in the comprehensive construction of a well-off society and building a prosperous and powerful socialist country, further, the employment problem of college art students more related to China's socialist modernization construction, maintain social stability and global issues. How to further better play a role of Ideological and political education work in Colleges and universities should play in the employment of college students of 
art, is the decentralization of the current new situation in Ideological and political education workers in front of an important research topic.

The ideological and political workers in Colleges and universities should be fully aware of the work of Ideological and political education in the employment guidance of college students of art the important role of, and actively take more effective measures to strengthen the work of Ideological and political education, and strive to cultivate the art students' positive employment knowledge and excellent quality of employment, help art students scientifically to establish the employment concept, can be in a normal state of mind of a common laborer product to very involvement in employment competition activities, the smooth realization of the art students successful employment, to actively promote the healthy development of the economy of our country, make an important contribution to the building of a harmonious socialist society.

The scientific analysis of the current situation of Ideological and political education from the perspective of the employment of college art students, employment idea and the employment status of art students' scientific investigation, through a detailed analysis of the questionnaire found that art students in ordinary college and other professional college students there are some differences in the employment of thought, and the survey found art the ideological and political education has made a profound analysis, find out the specific reasons, and on how to further strengthen art college students' employment guidance education and the ideological and political education, the organic combination of the two in order to improve the effect of Ideological and political education conducted in-depth research, and puts forward some specific measures: first, to strengthen the students employment management, put an end to violations of law in employment; strengthen art college students' employment education, the implementation of full employment education; three, enrich the art students' Ideological and political education content; four, the ideological and political education innovation methods and means; five, strengthen the construction of Ideological and political education work team. It is hoped that the results of this research can help the ideological and political education reform of college students in our country.

\section{CONFLICT OF INTEREST}

The authors confirm that this article content has no conflict of interest.

\section{ACKNOWLEDGEMENTS}

Declared none.

\section{REFERENCES}

[1] "Static University Ideological and political education content system research," South China University of Technology, vol. 8 pp. $35-45,2010$.

[2] Wang Feng, Dai Rui. "Employment education is the deepening and development of moral education in Colleges and universities." Research, vol. 5 pp. 55-65, 2003.

[3] B. Zheng, "The study on the ideological and political education of university based on the human-oriented," Journal of Henan University, vol. 5, pp. 30-45, 2005.

[4] G. Zhang, "The philosophical attribute and scientific attribute of the theory of Marx," Northeast Petroleum University, vol. 2, pp. 32-45, 2012.

[5] T. Song, "History and self realization of the," Heilongjiang University master's thesis, 2012.

[6] W. Ding, "Guangxi vocational students' employment ability research," Central South University, vol. 3, pp. 30-49, 2012.

[7] F. Wang, "Overview of employent theory and research new trends," Journal of Guangxi University of Finance and Economics, vol. 7, pp. 25-45, 2009.

[8] L. Yun, "The research on the career guidance for the graduates of the Art College under the new situation," 2011.

[9] Xianning, "The employment of college students from the perspective of Ideological and political education study," Changsha Polytechnic University Master thesis, 2009.

[10] X. Liao, "The effectiveness of College Ideological and political education of the status quo and Countermeasures," Zhejiang Normal University master thesis, 2011.

[11] Growth group, "Research on the employment of university students." Wuhan University doctoral thesis, 2010.

[12] Y. Chen, "The research on the ideological and political education of students in art colleges," East China Normal University, 2010.

[13] H. Chen, "Study on the integration of," Inheritance Culture And Ideological And Political Education Of College Students Employment Ability, vol. 9, pp. 58-65, 2010.

[14] D. Sun, "Research on the expansion of employment strategy in Heilongjiang province," Heilongjiang University, vol. 8, pp. 30-50, 2013.

[15] Y. Zhang, and W. ed. Chen, "Effectiveness of College Ideology," Beijing: Higher Education Press, 2001. 